\title{
THE SPATIAL CONCENTRATION OF ILLEGAL RESIDENCE AND NEIGHBORHOOD SAFETY
}

\author{
ARJEN LEERKES \\ Erasmus University Rotterdam
}

\author{
WIM BERNASCO \\ Netherlands Institute for the Study of Crime and Law Enforcement
}

\begin{abstract}
Has the spatial concentration of illegal residence in urban environments become a relevant determinant of objective and subjective neighborhood safety? Using quantitative data from various sources on four large metropolitan areas in The Netherlands, this explorative study shows that the elevated levels of fear of crime and violence reported by residents in neighborhoods where illegal residence is spatially concentrated cannot be attributed to the presence of illegal migrants. At the same time, there is a modest positive correlation between the rate of illegal residence and covert property crimes in particular. Qualitative fieldwork in two neighborhoods helps explain why the spatial concentration of illegal residence appears to have different effects for different aspects of neighborhood safety, and why the negative effects tend to be limited.
\end{abstract}

\begin{abstract}
6.7 he illegal migrant" has become a permanent social figure in most societies where governments are regulating and selectively restricting international migration. Substantial rates of illegal residence can be observed in the United States (Cornelius, Tsuda, Martin, \& Hollifield, 2004; Ngai, 2004), the European Union (Düvell, 2006), Japan (Sassen, 1991), as well as in (transit) countries like Turkey, Russia, Mexico, and Malaysia (Bade, 2004; Schloenhardt, 2001). A large proportion of illegal residence tends to be concentrated in deprived urban neighborhoods (Alt, 2003; Burgers, 1998; Courau, 2008, p. 28; Leerkes, Engbersen, \& Van San, 2007). In some neighborhoods in The Netherlands, the rate of illegal residence appears to be as high as $8 \%$ (Leerkes, Van San, Engbersen, Cruijff, \& Van der Heijden, 2004). This is substantially higher than the estimated national average of about $1 \%$ (Leerkes et al., 2004). In countries where the national rate is higher than 1\% — current estimates for the United States are at 3\% (Martin, 2004, p. 60) - the rate of illegal residence in concentration areas is likely to be higher than in The Netherlands.

This spatial concentration leads to questions that have not been extensively dealt with in the literature on illegal residence or on neighborhood safety. Several studies have analyzed how illegal

Direct correspondence to: Arjen Leerkes, Assistant Professor of Sociology at the Erasmus University Rotterdam, Postbus 1738, 3000 DR Rotterdam, The Netherlands, and Researcher at the Research and Documentation Centre (WODC), Dutch Ministry of Justice.E-mail: leerkes@fsw.eur.nl.
\end{abstract}

JOURNAL OF URBAN AFFAIRS, Volume 32, Number 3, pages 367-392.

Copyright (C) 2010 Urban Affairs Association

All rights of reproduction in any form reserved.

ISSN: 0735-2166.

DOI: 10.1111/j.1467-9906.2010.00493.x 
migrants are incorporated into their countries of settlement (see, for instance, Alt, 1999; Burgers, 1998; Ehrenreich, 2002; Engbersen, 1996; Mahler, 1995; Ngai, 2004) and a handful of studies have paid attention to crime among illegal migrants (Alt, 1999; Engbersen \& Van der Leun, 2001; Leerkes, 2009; McDonald, 1997; Scalia, 1996, 2002; Zaitch, 2002), but no other study has ever explored the consequences of concentrated illegal residence for neighborhood safety.

How safe are neighborhoods where concentrations of illegal migrants live? Is there more crime, or less? Do people feel more unsafe, or less so? What is the impact of the presence of illegal migrants and their specific social position as a consequence of their illegal residence status? These are the main research questions in this article, which uses data about The Netherlands.

There are two theoretical reasons for exploring the relation between illegal residence and neighborhood crime. First, it is plausible that the presence of illegal migrants will impact neighborhood crime, though perhaps in complex and differential ways. It can be hypothesized that illegal migrants are likely to shun police contacts more than legal residents do as these may lead to expulsion and long periods of Aliens' Detention. This tendency, which is assumed to have a deterrent effect on offending, has been dubbed the "deterrence thesis" (Van der Leun, 2003). Conversely, a number of illegal migrants appear to commit subsistence crime under the influence of having illegal residence status; in The Netherlands in particular, having illegal residence status increasingly bars people from the most legal means of satisfying conventional needs, such as the formal labor market, social housing, and social securities. Illegal migrants also appear to be at risk of becoming involved in hard drug use in the context of such a policy of "institutional exclusion," particularly in case of homelessness. This may incite crimes to finance drug use, such as house burglary (Leerkes, 2009). In the literature, this second hypothesized effect is known as the marginalization thesis (Engbersen \& Van der Leun, 2001; Engbersen, Van der Leun, \& De Boom, 2007). The marginalization thesis is increasingly relevant for other EU countries and the United States, where there is also an apparent tendency to discourage illegal residence by means of institutional exclusion. ${ }^{1}$

The second theoretical reason is related to Shaw and McKay's (1942) classic, often replicated, finding that much street crime centers in poor, ethnically mixed neighborhoods with high levels of social disorganization. These are precisely the sort of neighborhoods where illegal migrants tend to settle. This raises the question whether illegal residence constitutes, in a more indirect way, an additional burden for the safety of the poor and ethnically mixed neighborhoods in the large cities. Even if it would turn out that illegal migrants tend to comply with social rules that are important for neighborhood safety, their concentrated presence may erode safety to the extent that it weakens neighborhood organization even further. Because of detention and expulsion risks, illegal migrants are understandably less likely to report social disorder to the police or to correct deviant behavior in the neighborhood in informal ways as it may entail a risk on police contacts.

The reasons for examining the relationship between illegal residence and subjective neighborhood safety are in line with the above: if illegal residence would turn out to impact objective safety, it is likely to impact subjective safety indirectly in so far as neighborhood crime is among the determinants of subjective safety. Besides this, it can be hypothesized that through the same social mechanisms - that is, deterrence, marginalization, and social disorganization-the presence of illegal migrants may influence the degree of compliance with various social rules that are important for neighborhood safety, particularly perceived safety, even if the breaking of these rules is not punishable as a crime. Examples in point are hanging around in public spaces or treating passers-by with subtle aggression. Moreover, the degree to which illegal residence is perceived as a threat to neighborhood safety is a relevant research topic in and of itself, regardless of the extent to which illegal residence is actually a threat in terms of crime. Established social strata often associate outsiders with crime and disorder in order to mark differences in status and prestige (Elias \& Scotson, 1965). Of old, this also pertains to immigrants from poorer and 
culturally distant regions (Angel-Ajani, 2003; Van Heek, 1936). In recent years, public discourse increasingly links migration to questions of crime and security once again (Bigo, 2001; Huysman, 2000).

The latter observation constitutes the social reason for conducting this study. Empirical scientific research in this field can expose myths that are persistent in society, and can enlarge the space for a more nuanced discussion on the basis of verifiable assertions (cf. Elias, 1939).

This article explores the aforementioned research questions with data from a diverse array of sources. Beside police records, social surveys and administrative data, it uses qualitative fieldwork data that were collected in two Dutch urban areas where illegal residence is spatially concentrated.

The quantitative data are analyzed first in order to assess whether, and how, the rate of illegal residence in urban neighborhoods is associated with indicators of objective and subjective neighborhood safety. Subsequently, we assess whether the qualitative findings confirm the quantitative findings, and whether the fieldwork provides additional information to explain the established statistical relations (or the absence of such relations). In this way, we hope to contribute to the integration of quantitative and qualitative perspectives in the literature on public safety (for the desirability of this integration, see Ditton \& Farrall, 2000; Hale, 1996).

\section{THEORETICAL STARTING POINTS}

\section{Illegal Residence}

Illegal migrants in The Netherlands come from over 200 countries. The largest groups are Turks, Moroccans, Algerians, and Surinamese, generally chain migrants with settled family in The Netherlands. In the course of the 1990s, the numbers and proportions of Eastern Europeans, mostly labor migrants and rejected asylum seekers, have risen.

To understand the social position of illegal migrants, we have to consider the opportunity structure for illegal residence as a whole, that is, more than simply the state policies on immigration and illegal residence. Illegal migrants are incorporated into Dutch society in several ways, even though the state tries to exclude these migrants in various ways. Differences in social incorporation correspond to differences in life chances. Established immigrants from some countries, for example Turkey, have formed closely knit social networks in The Netherlands. Illegal newcomers from these countries can usually count on support from settled family members, other relatives, or people who are from the same region in the country of origin. Examples of assistance are temporary inclusion in the family, borrowing of health insurance cards, and finding a partner or a house to subrent informally. Minorities with a strong tradition of ethnic entrepreneurship such as the Chinese and Turks also provide informal work opportunities in ethnic niches. Those who happen to possess less social capital (Bourdieu, 1983; Portes, 1998), such as illegal pioneers or chain migrants from relatively fragmented ethnic groups like the Moroccans, have to rely on their own resources to a greater degree. Previous research suggests that they are more prone to become marginalized and may more readily become involved in crime (Engbersen \& Van der Leun, 2001; Engbersen et al., 2007).

Eastern European immigrants do not usually have ties with established countrymen in The Netherlands. They often work for Dutch entrepreneurs, in horticulture, for example. Some occupy sought-after jobs, albeit in the informal economy-think of the illegal plumber-but most do work that is not highly esteemed by the legal population (De Bakker, 2001).

The research period - the quantitative data pertain to 1997-2003, while the qualitative fieldwork was carried out between 2003 and early 2006-predates the inclusion of countries like Poland (2004) and Bulgaria (2007) into the EU. With an eye to this expansion, however, Bulgarians were allowed to visit Schengen countries, including The Netherlands, without visas since 
2001 (Van Gestel, 2006) as have Poles since the early 1990s, though as tourists they were not allowed to work. Those who stayed longer than three months - which many did-could be arrested for illegal residence. Thus, in comparison to most other illegal migrants, Eastern Europeans from non-EU countries had lower costs, monetary and otherwise, when they settled illegally, or when they returned to The Netherlands in the case of forced repatriation. Most migrants who lack a residence permit have to bridge larger geographical distances and must penetrate borders that are far less porous. Such differences in migration costs and motives influence behavioral opportunities and preferences in the country of destination.

The geographical proximity of Eastern Europe and the smaller political distance to the European Union made illegal migrants from Eastern Europe particularly attractive as seasonal workers in Dutch horticulture. The same spatial and political conditions had the unintended side-effect of small groups of Eastern European "tourists" traveling to Western Europe with intent to commit crimes, mostly burglary, car theft, or pickpocketing (Van Tilburg \& Lammers, 2004). If they stayed longer than three months, or crossed the border illegally, they became part of the illegal population.

\section{Objective and Subjective Safety in Urban Neighborhoods}

Safety has objective and subjective components. Objective safety pertains to victimization, that is, the measurable recorded experience of becoming a victim of a criminal act. Subjective safety concerns the assessment by residents of the local crime and nuisance rate, and the extent to which they feel safe, particularly in their own neighborhoods (Vanderveen, 2006). It is not only-nor even primarily - the crime rate that determines subjective safety; other signs of disorder are more important (Lewis \& Salem, 1986; Markowitz, Bellair, Liska, \& Liu, 2001; Taylor \& Hale, 1986). Examples of the latter are groups hanging around in public places and begging, being noisy, addressing strangers, or showing symptoms of alcohol or drug use. Since Goffman's (1963, 1971) work, we know that people expect from each other-and of themselves-that certain unwritten rules be observed in public space. Transgressions can produce fear and unease. Besides this, Goffman showed that the absence of shared behavioral expectations-in sociology also known as anomie - can cause feelings of risk and discomfort. Hence, norm violations, on top of a lack of shared norms as regards "what is appropriate" in public space, may contribute to a fear of crime. Signs of disorder that are, strictly speaking, physical—such as rubbish in the street, graffiti, vandalized pay phones, and bus shelters-may cause anxiety in many residents, and may eventually increase crime rates as more people withdraw from public space.

There is no one-to-one relationship between objective and subjective safety. People who live in comparable objective circumstances with regard to crime, or who have become victims of a particular crime, usually do not feel safe to the same degree (Hale, 1996). It turns out, for instance, that vulnerable residents are often more frightened than people who consider themselves relatively invulnerable. This is the primary reason why women, the elderly, and singles tend to feel less safe than men, young adults, and cohabitants (Killias, 1990).

Shaw and McKay's (1942) ecological studies demonstrated that a large share of the juveniles who are responsible for street crime and disorder live in socially disorganized neighborhoods: poor neighborhoods with unstable residential populations as well as much ethnic and cultural diversity. While later studies added a number of structural factors to this shortlist, Kornhauser (1978) suggested that the defining property of social disorganization is the inability of residents in local communities to realize common values or to solve commonly experienced problems. More recently, Sampson, Raudenbush, and Earls (1997) argued that the principal mediating construct between structural conditions of deprivation and violent crime is a community's level of collective efficacy. In communities with high levels of collective efficacy, residents have the motivation and 
the capacity to act on behalf of the common good because there is trust and solidarity among neighbors. Thus, collective efficacy is the combination of social cohesion and social control. If these qualities are lacking, consensus about respectable or acceptable norms is more difficult to achieve and the willingness on the part of residents to protect and defend each other, each other's property, or shared interests, for example by correcting each other's children, diminishes. Social disorganization also hampers the efforts of specialized agents of social control, like the police, to help preserve public order (Veléz, 2001). As a result, there is less resistance to antisocial behavior, including crimes, committed by residents and offenders from other areas. Groups that do not live up to widely shared social standards - such as bohemians, petty criminals, and homeless people_-often prefer disorganized areas and/or are successfully barred from the better organized neighborhoods.

\section{Analytical Strategy}

The following strategy is used for the quantitative analyses. First, we assess the extent to which there is a bivariate relationship between the degree of illegal residence and aspects of subjective neighborhood safety. Subsequently, it is assessed whether these relations persist when, in addition to the degree of illegal residence, measures of known determinants of neighborhood safety are entered in a multivariate model. If the degree of illegal residence affects neighborhood safety when these risk factors are included in the model, there is some circumstantial evidence that it could be a causal factor in neighborhood safety. If no association remains, the association between the degree of illegal residence and neighborhood safety is likely to be spurious, and possibly caused by the fact that immigrants often have few other choices than to live in neighborhoods already disorganized and unsafe to begin with.

When exploring the relation between illegal residence and subjective safety, we control for vulnerability, social disorganization, and criminal victimization. Because these variables are measured at different analytical levels, that is, the individual or household and the neighborhood level, we employ multilevel hierarchical linear models. When exploring the relation between illegal residence and objective safety, we use ordinary least squares regression because all variables we use there are at the neighborhood level; we then control for indicators of the structural neighborhood characteristics that are commonly assumed to lead to social disorganization (socioeconomic deprivation, residential turnover, and ethnic heterogeneity), and a rough proxy for the concentration of potential offenders with legal residence, to wit: the proportion of youngsters in the neighborhood.

\section{DATA AND ANALYTICAL STRATEGY}

\section{Data Sources}

The quantitative analyses apply to the residents of 596 residential neighborhoods in the police regions that cover the metropolitan areas of the four largest cities in The Netherlands: Amsterdam, Rotterdam, The Hague, and Utrecht. In line with previous Dutch research (Goudriaan, Wittebrood, \& Nieuwbeerta, 2006; Van Wilsem, Wittebrood, \& de Graaf, 2006), a neighborhood is defined in terms of a postcode area. Such areas contain on average roughly 2,000 households and 5,000 individuals. We combined information from four quantitative data sources. The Dutch Bureau for Statistics provides demographic, social, and economic statistics data on these neighborhoods on a regular basis (source 1). Data on homeownership were made available by the Ministry of Housing (source 2). 
Estimates of illegal residence in the neighborhoods were derived from the VAS, a police database dedicated to the registration of foreigners living in The Netherlands, including all apprehended illegal migrants (source 3 ). The rate of illegal residence is indicated by the number per 1,000 legal residents of registered residential addresses of illegal migrants who have been apprehended by the police somewhere in The Netherlands between January 1997 and October 2003. The number of individuals involved is quite substantial: 10,497 apprehensions with a registered residential address in the 596 neighborhoods.

The VAS mainly contains data on illegal migrants who have risked apprehension for some reason. Because the likelihood of apprehension increases with the degree of criminal involvement, criminal illegal migrants are likely to be overrepresented in this database; in $200343 \%$ of the apprehensions concerned crimes, mainly property crimes, identity fraud, and drug dealing, as well as some violence (Leerkes et al., 2004, pp. 24-25). Yet a large share of the apprehensions is not related to crime. Almost 50\% is related to illegal labor. Employers in The Netherlands are increasingly subjected to checks by the labor inspectorate. Furthermore, specific raids to trace illegal migrants have become more frequent, particularly in the large cities. These raids sometimes target criminal illegal migrants but are mainly directed at the phenomenon of what are called dosshouses. In these premises, which tend to be located in run-down areas, between 10 and 30 people, usually illegal migrants, rent a bunk bed or mattress for shorter or longer periods of time. In such cases, the apprehension is usually registered under the heading of "illegal residence," which is not a crime in The Netherlands. Eight percent of the apprehensions are the result of common misdemeanors like fare-dodging or neglecting traffic lights. Such infractions are quite common in The Netherlands and are not typical of criminal illegal migrants.

The overrepresentation of criminal illegal migrants in the VAS is partially compensated for by a lower likelihood of such migrants having a registered residential address; it turns out that relatively few illegal migrants who are apprehended because of a crime have a residential address that has been registered by the police. ${ }^{2}$ In conclusion, the VAS data are unlikely to be completely representative for the total illegal population and we should treat the data with caution. Yet, this selectivity should not be exaggerated because other groups are well represented as well. Good results have already been obtained using these data. They helped to unearth statistical patterns that confirmed theoretical expectations as well as qualitative empirical findings in The Netherlands and elsewhere (see, e.g., Engbersen, Van San, \& Leerkes, 2006; Leerkes et al., 2007).

Four variables were chosen to measure the level of social disorganization in the neighborhoods: the percentage of low-income residents, the percentage of homeownership, the percentage of legal non-Western ethnic minorities, and the percentage of single-person households. ${ }^{3}$ It is not uncommon in the literature on neighborhood safety to use such determinants, or at least correlates, of social disorganization, rather than measuring social disorganization directly (see, e.g., Wei, Hipwell, Pardini, Beyers, \& Loeber, 2005). We discuss each of them in turn.

Statistics Netherlands defines low-income residents as residents with a disposable income of less than 12,045 euro per year, which comprised the first $40 \%$ of the income pyramid in The Netherlands in 1998. Other studies suggest that neighborhood crime does not increase linearly if poverty increases but tends to be associated with the highest degrees of neighborhood deprivation (cf. Hannon and Knapp, 2003; Hannon, 2005). For this reason, we controlled for proportion of low income to the third power, which indeed turned out to result in a better model fit than proportion or proportion squared. ${ }^{4}$

Instead of using a more direct measure of residential mobility, which probably would have been preferable if it had been available for postcode areas, we used the percentage of homeownership as an indicator for social disorganization. ${ }^{5}$ For various reasons, homeownership is linked to residential attachment and residential stability (see, for instance, Taylor, 1996; Brown, Perkins, \& Brown, 2003), and in The Netherlands annual mobility rates are more than 50\% higher 
among renters than among house owners (Van Ommeren, 2006). The percentage of legal nonWestern ethnic minorities was chosen because in The Netherlands it correlates strongly with more complex and theoretically superior measures of ethnic heterogeneity that take into account the mix of specific ethnic groups (Bernasco \& Luykx, 2003).

It is somewhat uncommon in the international literature to take the percentage of single-person households as an indicator of social disorganization; researchers tend to use the percentage of single-parent families for this purpose. We had to choose the former variable because the latter was unavailable for postcode areas. Nonetheless, the percentage of single-person households has been used before in Dutch research (see, for instance, Dijkink, 1987), and this choice can be defended on theoretical grounds (see, for instance, Sampson and Laub (1993) on the relationship between social control and marriage).

Assessments of neighborhood safety were taken from the Police Monitor (PM), a biannual national survey on criminal victimization, fear of crime, local physical and social disorder, and satisfaction with police services (source 4). To improve the reliability of the assessments, the surveys for the years 1997, 1999, 2001, and 2003 were taken together. In the 596 neighborhoods, 78,927 respondents were interviewed over these four years. Ethnic minorities are underrepresented, in part because the survey is administered in the Dutch language only (Schoen, Defize, \& Bakker, 2000). The participation of illegal migrants in the survey is possible, but not very likely.

Vulnerability is indicated by the following characteristics of the respondents in the Police Monitor: being female, being middle-aged or older, membership of an ethnic minority (Covington \& Taylor, 1991), unemployment, low educational attainment, and being part of a small household.

The survey measures the number of victimizations of specific types of offences during the past 12 months. For every offence except residential burglary, respondents were asked to report whether the offence took place in their own neighborhood or elsewhere. For the analyses reported here, only victimization in the respondent's neighborhood is used (see Table 1 for descriptive statistics per offence type).

The criminal victimization variable that is used in the analysis of subjective safety is a factor score of two measures: "number of incidents of criminal victimization during past year" and "number of types of incidents of criminal victimization during past year." The "neighborhood victimization rate" refers to the average number of victimizations of any type, experienced by other neighborhood members participating in the survey.

The PM survey contains various items that tap subjective aspects of neighborhood safety. Some specifically apply to fear of crime, while others refer to annoyances, such as noise nuisance, or signs of physical deterioration, or neglect. Using factor analysis, the items were reduced to six dimensions: ${ }^{7}$

(1) Feeling unsafe. Included items are "Do you ever feel unsafe?" "Do you ever avoid certain places because they are unsafe?" "Do you ever refuse to open the front door because it is unsafe?" "Do you ever leave things at home for fear of being robbed?" "Do you ever take an alternative route to avoid going through unsafe places?"

(2) Perceived magnitude of property crimes. Included items are "How often does this occur in your neighborhood?" For each of the following: bicycle theft, theft from cars, theft of cars, burglary.

(3) Perceived magnitude of physical deterioration. Included items are "How often does this occur in your neighborhood?" For each of the following: litter and dog droppings on street, vandalism, graffiti.

(4) Perceived magnitude of social deterioration. Included items are "How often does this occur in your neighborhood?" For each of the following: people who are drunk, people who annoy others, people who make threats, violent crimes, drug crimes. 
TABLE 1

Descriptive Statistics ( $N=78,927$ Respondents, $N=596$ Neighborhoods)

\begin{tabular}{|c|c|c|c|c|}
\hline & Min & Max & Average & Std. Dev. \\
\hline \multicolumn{5}{|l|}{ Independent variables: } \\
\hline \multicolumn{5}{|l|}{ Individual level } \\
\hline Sex $($ male $=1)$ & 0 & 1 & 0.47 & 0.5 \\
\hline Age (years) & 15 & 98 & 48.5 & 18.1 \\
\hline Dutch by origin (self-categorization) & 0 & 1 & 0.89 & 0.31 \\
\hline Education ${ }^{\mathrm{a}}$ & 1 & 7 & 4.3 & 1.9 \\
\hline Employment (employed > 15 hours/week) & 0 & 1 & 0.5 & 0.5 \\
\hline Household size & 1 & 15 & 2.3 & 1.3 \\
\hline Criminal victimization (scale) & -0.68 & 28.0 & 0.0 & 1.0 \\
\hline \multicolumn{5}{|l|}{ Neighborhood level } \\
\hline Rate of illegal residence (no. per 1,000) & 0 & 130 & 2.5 & 4.7 \\
\hline Neighborhood victimization rate (no. per 100) & 0 & 6.3 & 0.75 & 0.4 \\
\hline Percentage of singles & 6 & 79 & 29.9 & 14.0 \\
\hline Percentage of private homeownership & 0 & 100 & 39.7 & 22.1 \\
\hline Percent of low-income residents (third power/1,000) & 0.5 & 53.1 & 6.6 & 40.3 \\
\hline Percentage of non-Western migrants (1st and 2nd generation) & 1 & 82 & 17.4 & 17.5 \\
\hline Percentage of residents aged $14-25$ years & 3 & 30 & 12.1 & 2.9 \\
\hline \multirow{2}{*}{\multicolumn{5}{|c|}{$\begin{array}{l}\text { Dependent variables: } \\
\text { Individual level }\end{array}$}} \\
\hline & & & & \\
\hline Feeling unsafe (scale) & -12.5 & 18.1 & 0.0 & 10 \\
\hline Property crimes (scale) & -17.4 & 11.2 & 0.0 & 10 \\
\hline Physical deterioration (scale) & -17.9 & 13.2 & 0.0 & 10 \\
\hline Social deterioration (scale) & -8.4 & 23.6 & 0.0 & 10 \\
\hline Nuisances (scale) & -10.1 & 20.3 & 0.0 & 10 \\
\hline Traffic nuisances (scale) & -14.4 & 13.2 & 0.0 & 10 \\
\hline \multicolumn{5}{|l|}{ Neighborhood level ${ }^{b}$} \\
\hline Total victimization rate (no. per 100) & 0 & 588 & 95.7 & 62.5 \\
\hline Theft, including: & 0 & 200 & 34 & 24.8 \\
\hline Bicycle theft & 0 & 200 & 6 & 5.7 \\
\hline Car theft & 0 & 12.5 & 1.1 & 1.5 \\
\hline Theft from car & 0 & 200 & 10.6 & 11.6 \\
\hline Burglary (including attempt) & 0 & 143.5 & 10.7 & 8.4 \\
\hline Robbery & 0 & 2.6 & 0.2 & 0.4 \\
\hline Pickpocketing & 0 & 20 & 1.0 & 1.2 \\
\hline Other theft & 0 & 100 & 4.5 & 4.5 \\
\hline Vandalism, including: & 0 & 208.9 & 39.8 & 25.8 \\
\hline Purposeful car damage & 0 & 180.3 & 31.2 & 20 \\
\hline Other vandalism & 0 & 80.1 & 8.6 & 9 \\
\hline Violence, including: & 0 & 166.7 & 4.3 & 7.1 \\
\hline Threaten with violence & 0 & 166.7 & 3.8 & 6.5 \\
\hline Assault & 0 & 37.6 & 0.5 & 1.9 \\
\hline Other crimes, including: & 0 & 344.8 & 17.6 & 20.4 \\
\hline Leaving place of accident & 0 & 33.3 & 2.5 & 3.7 \\
\hline Collision & 0 & 100 & 13 & 14.4 \\
\hline Other crimes & 0 & 326.7 & 2 & 11.7 \\
\hline
\end{tabular}

aSeven levels of education: primary education, lower vocational training, secondary general training, intermediary vocational training, grammar/high school, higher vocational training, and university.

${ }^{b}$ In OLS regression neighborhoods are weighted proportionally to the number of residents.

Sources: Statistics Netherlands, Politiemonitor Bevolking (97-03), Vreemdelingen Administratie Systeem (1997-October 2003), Geomarktprofiel 1998. 
(5) Perceived magnitude of nuisances. Included items are "How often does this occur in your neighborhood?" For each of the following: noise nuisance (except traffic noise), juveniles hanging around, nuisance behavior by immediate neighbors.

(6) Perceived magnitude of traffic nuisances. Included items are "How often does this occur in your neighborhood?" For each of the following: aggressive behavior in traffic, loud traffic noise, speeding, and traffic accidents.

\section{Strengths and Limitations of Victimization Surveys}

Victimization surveys such as the PM are valuable because they supplement police records by providing insight in the "dark number" of crimes unreported to the police, and because they tap subjective aspects of public safety. But they do have their drawbacks. For example, crimes against businesses and organizations (shoplifting, commercial burglary, fraud) and the more consensual, "victimless" crimes (prostitution, drug dealing) are not touched upon, although in the PM the latter may be reported under the heading of subjectively perceived nuisance and social deterioration. Davies, Francis, and Jupp (2003) provide a comprehensive overview of the restrictions that apply to victimization surveys.

\section{Qualitative Sources}

The fieldwork was carried out in the Bospolder-Tussendijken neighborhood in Rotterdam and the De Schilderswijk neighborhood in The Hague. Both neighborhoods house many first- or second-generation non-Western immigrants. In Bospolder-Tussendijken, 65\% of the population is of non-Dutch origin and is mostly Turkish, Moroccan, Cape Verdean, or Surinamese. In De Schilderswijk, this proportion is $85 \%$; most residents are Turkish, Surinamese, Moroccan, or Netherlands-Antillean. The value of real estate is typically low. Many Dutch citizens who could afford to have moved to the suburbs. The neighborhoods also have a sizeable student population.

The neighborhoods were selected because police data indicated that illegal residence was a common phenomenon in both. On top of that, they represented two faces of illegal residence. In Bospolder-Tussendijken, a relatively large percentage of the apprehended illegal migrants were arrested because of crimes, while in De Schilderswijk the reason for apprehension was mostly illegal residence and illegal labor.

Twenty professionals were interviewed who could provide a view as to whether, how, and why the presence of illegal migrants impacts neighborhood safety and livability. They included police officers some of whom were from the Aliens police, representatives of municipalities and housing corporations, and neighborhood social workers. Furthermore, a team of trained interviewers conducted interviews with 70 illegal migrants from six different countries of origin, and 45 landlords who provided accommodation to illegal migrants. The qualitative study, which was subsidized by the Ministry of Housing, focused on the local housing situation; illegal migrants were not asked to report on victimization or safety issues, but on issues of housing and reasons for settling in the neighborhood. The results of these interviews did, however, provide useful information about the ways in which illegal migrants were embedded in the two neighborhoods. A more comprehensive description of the fieldwork has been published elsewhere (Engbersen et al., 2006; Leerkes et al., 2004; Leerkes et al., 2007).

Moreover, 101 sociology students each interviewed a resident about social relations in the neighborhood in general, and subjective neighborhood safety in particular. These interviews, which took place until March 2006, were practiced in class and supervised by one of the authors. The questionnaires contained some directed questions on illegal migrants that were posed later 
during the interview, in order to allow spontaneous answers and relations to emerge during the first phase. To increase sample variation the students, who typically worked in pairs, were to interview a male and a female, a younger and an older, a native and a nonnative resident; the combination of characteristics was not prescribed. The students recruited respondents by ringing doorbells or buttonholing people on the street. Most interviews, 66, took place in De Schilderswijk. Interviews were held with 43 Dutch (23 male, 25 female), 25 Turkish (20 male, 5 female), 19 Moroccan (13 male, 6 female), 5 Surinamese ( 3 males), 2 Netherlands Antillean (1 male, 1 female), and 7 residents from various other ethnic groups (6 male, 1 female). About half the sample was 30 55 years of age, one-third was above 55 and one-fifth was below 30. In line with the demographic structure of the neighborhoods, the older respondents were mostly Dutch, while the younger generations were predominantly of foreign origin.

A main limitation of the qualitative results is that they are based on the respondents' views and not on direct observations. The quantitative analyses are based on the registered local level of illegal residence, and do not depend on whether the respondents were conscious of certain effects.

The stories of illegal migrants, residents, and professionals could nonetheless be compared with each other, and with the quantitative findings. This triangulation provides additional validity, contributing to a plausible description and explanation of the relations between illegal residence and neighborhood safety.

\section{QUANTITATIVE FINDINGS}

\section{Illegal Residence and Perceived Risk in the Neighborhood}

The analysis starts with an exploration of the relationship between illegal residence and subjective neighborhood safety. Table 2 shows the effects of the rate of illegal residence on six dimensions of subjective safety, for five regression models that are increasingly comprehensive in terms of the number of independent variables included. Table 2 shows only the effects of the rate of illegal residence. Table 3 displays additional information for model IV, the most comprehensive model.

Model I summarizes the bivariate relations between the rate of illegal residence and insecurity. It shows that subjective safety decreases with the level of illegal residence, a conclusion that holds

TABLE 2

Unstandardized Effects of the Rate of Illegal Residence on Six Measures of Subjective Safety ( $N=$ 78,927 Respondents, $N=596$ Neighborhoods) ${ }^{\mathrm{a}}$

\begin{tabular}{llccrrc}
\hline Model & $\begin{array}{l}\text { Feeling } \\
\text { Unsafe }\end{array}$ & $\begin{array}{c}\text { Property } \\
\text { Crime }\end{array}$ & $\begin{array}{c}\text { Physical } \\
\text { Deterioration }\end{array}$ & $\begin{array}{c}\text { Social } \\
\text { Deterioration }\end{array}$ & Nuisances & $\begin{array}{c}\text { Traffic } \\
\text { Nuisances }\end{array}$ \\
\hline I & $0.193^{* * *}$ & $0.166^{* * *}$ & $0.179^{* * *}$ & $0.298^{* * *}$ & $0.183^{* * *}$ & $0.197^{* * *}$ \\
II & $0.192^{* * *}$ & $0.167^{* * *}$ & $0.179^{* * *}$ & $0.299^{* * *}$ & $0.183^{* * *}$ & $0.188^{* * *}$ \\
IIIa & $0.068^{* * *}$ & $0.080^{* * *}$ & $0.049^{* * *}$ & $0.156^{* * *}$ & $0.089^{* * *}$ & $0.100^{* *}$ \\
IIIb & -0.036 & -0.021 & -0.037 & -0.006 & -0.016 & 0.009 \\
IV & -0.039 & 0.008 & -0.037 & -0.007 & -0.020 & 0.008 \\
\hline
\end{tabular}

${ }^{* * *} p<0.01,{ }^{* *} p<0.05,{ }^{*} p<0.10$.

aLinear hierarchical regression models, all other effects not shown.

Sources: Statistics Netherlands, Politiemonitor Bevolking (97-03), Vreemdelingen Administratie Systeem (1997-October 2003), Geomarktprofiel 1998. 


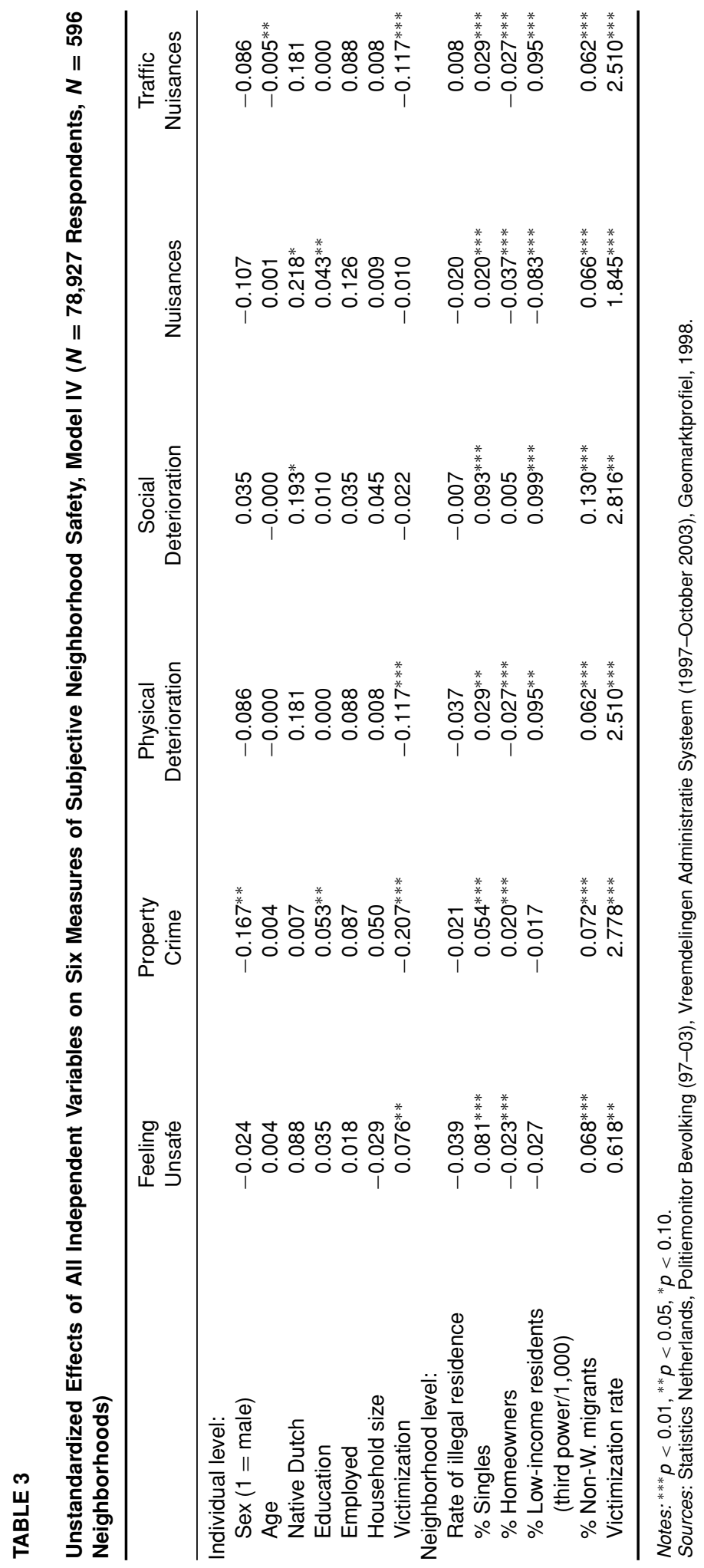


for all six aspects of subjective safety. Illegal migrants are overrepresented in neighborhoods where residents feel less comfortable and safe.

Should these lower levels of subjective safety be attributed to the presence of illegal migrants, to individual characteristics of residents, to other neighborhood characteristics, or to all these factors simultaneously? The second model (II) assesses whether the differences in vulnerability explain neighborhood differences in subjective safety. If that were the case, vulnerable social groups would be overrepresented in neighborhoods with high levels of illegal residence. Yet a comparison between models I and II shows that the effect of illegal residence on subjective safety does not diminish when the individual characteristics indicating vulnerability are taken into consideration. It seems that residents of neighborhoods with high levels of illegal residence are not individually predisposed to feel particularly unsafe. This is in line with the observation that in fact the demographic structure of the neighborhoods with the highest levels of illegal residence does not indicate vulnerability, since young males turn out to be overrepresented in such neighborhoods. ${ }^{8}$

Possibly the causes of the lower levels of safety should be sought in neighborhood characteristics. In model III, the indicators for social disorganization are added. A distinction is made between, on the one hand, demographic and economic indicators (percentage of singles and percentage of private homeownership in model IIIa) and, on the other hand, an ethnic-cultural indicator (percentage of legal non-Western immigrants in model IIIb).

The outcomes of model IIIa show that the effect of the rate of illegal residence on subjective safety decreases substantially when indicators for social disorganization are taken into account. It decreases to about one-third the initial size when neighborhood differences in the percentage of single-person households, private homeownership, and the third power of the percentage of low-income residents are added to the model. When the percentage of legal non-Western immigrants is included too (model IIIb), the effect of the rate of illegal residence disappears completely, for all six dimensions of subjective neighborhood safety. Interestingly, the effect of illegal residence on four of the six dimensions of subjective neighborhood safety even reverses, which suggests that the presence of illegal migrants may foster subjective safety and livability somewhat. Yet, these effects all lack statistical significance: if illegal residence directly impacts subjective neighborhood safety at all, its effects are too weak to be statistically detectable.

The final model (IV) introduces individual- and neighborhood-level variables of victimization. As expected, both the amount of individual victimization and the level of criminal victimization reported by other neighborhood residents decrease subjective safety on most of the six dimensions distinguished. The inclusion of the victimization variables, however, has no further consequences for the effects of the rate of illegal residence on subjective neighborhood safety.

\section{Illegal Residence and Criminal Victimization in the Neighborhood}

This section focuses on the relation between illegal residence and objective safety. Tables 4 and 5 follow the same structure as Tables 2 and 3, but have been transposed. Table 4 shows the effects of the rate of illegal residence on victimization rates for various types of crime. It does so for four different models, each more comprehensive than the one before. Table 5 demonstrates the complete outcomes of model III, including the estimated coefficients of all independent variables.

The rate of illegal residence correlates positively with all measured types of victimization except "other crimes" (see model I in Table 4). Evidently, the presence of illegal migrants tends to be a feature of neighborhoods with elevated victimization levels. Should high crime rates be attributed to the presence of illegal migrants in these neighborhoods? We cannot tell without adding controls for factors known to be related to neighborhood crime. 
TABLE 4

Standardized Effects of the Rate of Illegal Residence on Residents' Within-Neighborhood Victimization Rates ( $N=78,927$ Respondents, $N=596$ Neighborhoods) ${ }^{\text {a }}$

\begin{tabular}{|c|c|c|c|c|}
\hline Dependent Variables & Model I & Model Ila & Model Ilb & Model III \\
\hline Total victimization rate & $0.525^{* * *}$ & $0.259^{* * *}$ & $0.105^{* * *}$ & $0.104^{* *}$ \\
\hline Theft, including: & $0.554^{* * *}$ & $0.319 * * *$ & $0.162^{* * *}$ & $0.160^{* * *}$ \\
\hline Bicycle theft & $0.406 * * *$ & $0.185^{* * *}$ & $0.073^{*}$ & $0.071^{*}$ \\
\hline Car theft & $0.507^{* * *}$ & $0.377^{* * *}$ & $0.263^{* * *}$ & $0.263^{* * *}$ \\
\hline Theft from car & $0.608^{* * *}$ & $0.382^{* * *}$ & $0.172^{* * *}$ & $0.170^{* * *}$ \\
\hline Burglary (including attempt) & $0.282^{* * *}$ & $0.192^{* * *}$ & $0.181^{* * *}$ & $0.179 * * *$ \\
\hline Robbery & $0.325^{* * *}$ & $0.158^{* * *}$ & -0.006 & -0.005 \\
\hline Pickpocketing & $0.301^{* * *}$ & $0.129 * * *$ & $0.111^{* *}$ & $0.111^{* *}$ \\
\hline Other theft & $0.173^{* * *}$ & 0.003 & -0.098 & -0.099 \\
\hline Vandalism, including: & $0.488 * * *$ & $0.223^{* * *}$ & 0.066 & 0.062 \\
\hline Purposeful car damage & $0.509 * * *$ & $0.249^{* * *}$ & $0.075^{*}$ & 0.071 \\
\hline Other vandalism & $0.266 * * *$ & $0.088^{* *}$ & 0.022 & 0.019 \\
\hline Violence, including: & $0.228^{* * *}$ & $0.111^{* *}$ & 0.054 & 0.052 \\
\hline Threaten with violence & $0.223^{* * *}$ & $0.114^{* *}$ & 0.068 & 0.067 \\
\hline Assault ${ }^{b}$ & $0.196 * * *$ & 0.070 & -0.028 & -0.029 \\
\hline Other crimes, including: & $0.242^{* * *}$ & $0.086^{*}$ & 0.025 & 0.027 \\
\hline Leaving place of accident & $0.319 * * *$ & $0.156^{* * *}$ & 0.068 & 0.069 \\
\hline Collision ${ }^{c}$ & $0.239 * * *$ & 0.060 & -0.027 & -0.024 \\
\hline Other crimes & 0.028 & 0.027 & 0.055 & 0.054 \\
\hline
\end{tabular}

${ }^{* * *} p<0.01,{ }^{* *} p<0.05,{ }^{*} p<0.10$.

aOLS regression analyses, all other effects not shown.

${ }^{b}$ Because the distribution of assault victimization across neighborhoods is very skewed, we applied a square-root transformation in order to approximate the normal distribution.

'This category also includes noncrimes: accidental collision does not constitute a crime if the driver has a driver's license. Such distinctions are not made in the survey.

Sources: Statistics Netherlands, Politiemonitor Bevolking (97-03), Vreemdelingen Administratie Systeem (1997-October 2003), Geomarktprofiel 1998.

As in the previous section the effects of the rate of illegal residence decline substantially when the percentage of single-person households, the percentage of homeownership, and the third power of the percentage of low-income residents are entered in the model (model IIa). The effects decline further when the percentage of legal non-Western immigrants is included as an additional indicator of social disorganization (model IIb). Yet unlike the results for the subjective aspects of safety, the positive effects do not completely disappear for all types of crime. The rate of property offences in particular still correlates with the rate of illegal residence. Adding the percentage of juveniles (model III) reduces the effects of the rate of illegal residence somewhat further for most types of crime, but does not change this pattern. Note also that the effect reduction differs substantially across crime categories (compare models I and III in Table 4). It turns out that the reduction for vandalism $(87 \%)$, violent crime $(77 \%)$ and other crime $(89 \%)$ is larger than for property crime $(71 \%)$. Thus, although most of the association between the rate of illegal residence and objective neighborhood safety is accounted for by aspects of social disorganization, illegal residence still appears to have a modest independent effect on victimization of most types of property crime. It does not have such an independent effect on violence and vandalism, perhaps apart from car vandalism (car vandalism is distinguished as a separate crime type in the PM because it often concerns attempted thefts from cars, and may thus represent property crime). Interestingly, similar disparities can be observed within crime categories: note that the effect reduction is stronger for "robbery" $(>100 \%)$ than for pickpocketing $(63 \%)$. Robbery is an overt 


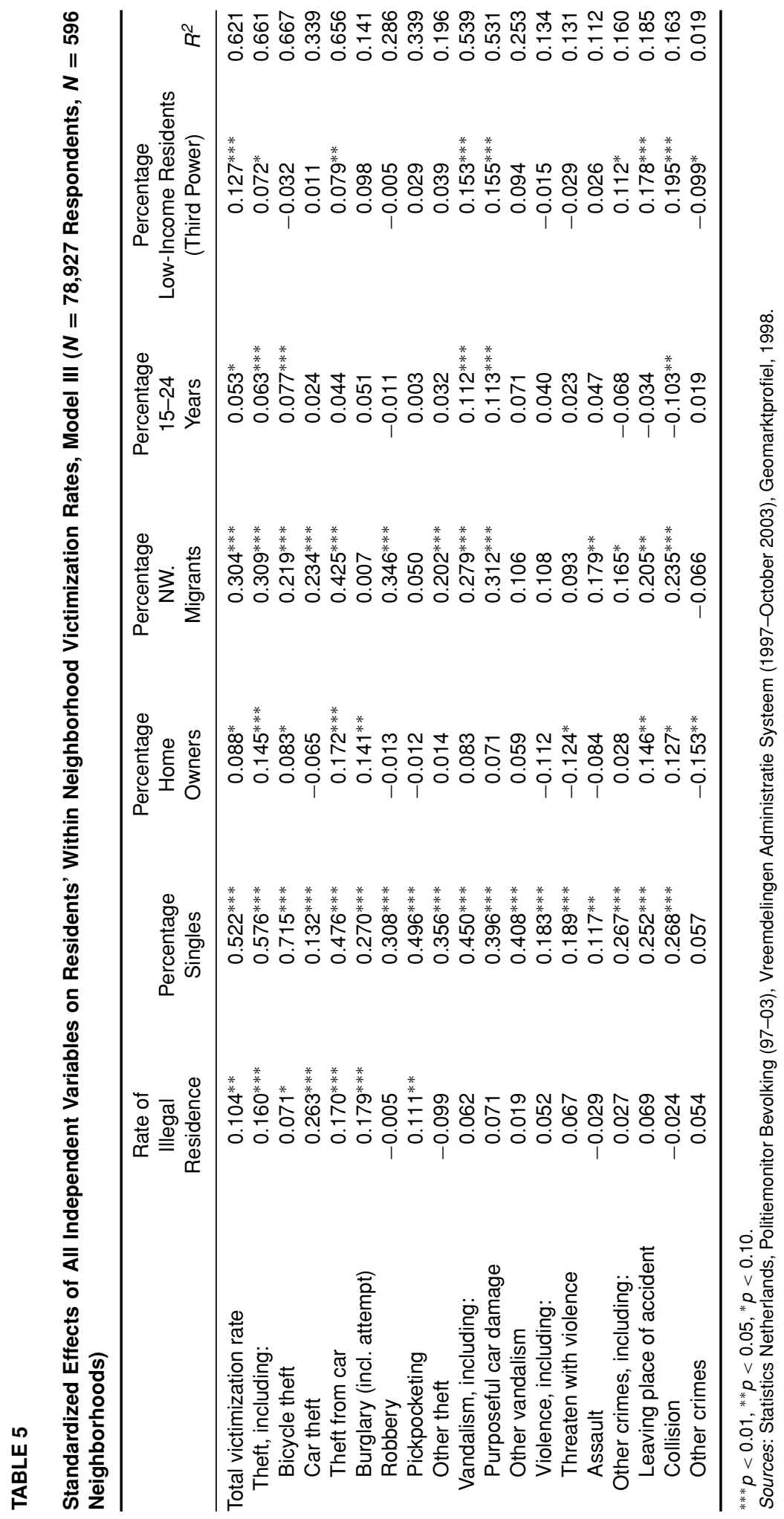


property crime because it requires that offender disclose himself to the victim. Pickpocketing is a covert property crime.

These figures do not necessarily imply, of course, that illegal residents are responsible for the elevated covert property crime rates. The effects may also point at unmeasured causal factors that are correlated, causally or otherwise, with illegal residence. Possibly the rate of illegal residence is correlated with elements of social disorganization that have not been adequately measured with the available indicators. Such a correlation could have differing causes. It may be that the rate of illegal residence increases social disorganization beyond levels indicated by the variables that have been used here (percentage of singles, legal non-Western migrants, and private homeownership). This concern was, in fact, the second reason to conduct this study. Another possibility is that unmeasured elements of social disorganization are not a consequence of illegal residence but a cause. It could be, for instance, that high rates of social disorganization in a neighborhood facilitate the local level of illegal residence; illegal residence as such constitutes a form of rule violation-if only a violation of state rules-that may, in part, flourish in conditions of reduced social control.

We are nonetheless inclined to attribute the observed patterns to the phenomenon of selective criminality among illegal migrants, rather than to unmeasured factors. First, the robust correlation between the rate of illegal residence and covert property crimes in particular confirms what is generally found about the involvement of illegal migrants in crime. Compared to legal offenders of the same age and ethnic background, illegal migrants are more likely to be involved in instrumental offences such as nonviolent theft (Leerkes, 2004). A preference for covert property crimes has some logic for illegal offenders because it can be assumed that most illegal migrants will seek to minimize the chances of police arrest in order to minimize the risk of expulsion: covert crimes are more difficult for the police to solve. We also know that illegal migrants are less likely to be involved in what are called expressive or symbolic offences, such as assaults and vandalism. It appears that the involvement in the latter types of crimes is diminished because they increase illegal migrants' detention and expulsion risks, yet are not instrumental to subsistence ends. Evidence for a similar selective involvement of illegal migrants in crime has also been mustered for the United States (McDonald, 1997; Wolf, 1988), Belgium (Van Meeteren, Van San, \& Engbersen, 2008) and Germany (Alt, 1999).

A second reason to attribute the statistical patterns to selective offending by criminal illegal migrants is that we would expect to find similar positive effects on violence and vandalism under the hypothesis that the rate of illegal residence is merely associated with factors that have not been adequately controlled for in this study, such as unmeasured social disorganization.

Third, the fieldwork (see hereafter) suggests that the presence of illegal migrants does not necessarily produce a large decline in social organization, since there are various types of social ties between the legal and the illegal population.

A part of the effect of the rate of illegal residence on property crimes may be the result of criminal migration among illegal migrants, particularly from Eastern Europe. Such offenders tend to commit property crimes as well. While these crimes occur in illegal residence, they are not "caused" or conditioned by illegal residence status. In contrast to subsistence crime, they should not be understood as an adaptation by illegal migrants to the potential consequences of having illegal residence status in the context of a policy of institutional exclusion.

A further qualification that should be made: the effect of the rate of illegal residence on property crimes may be overestimated here to the extent that criminal illegal migrants are indeed overrepresented in the VAS data, as we mentioned in the section on data.

We would like to conclude this section with the comment that there is some evidence that the fear of being expelled need not always inhibit crime, but may, in fact, promote certain crimes. The effect reduction of the crime of "causing traffic accident and leaving scene" $(78 \%)$ is, in any 
event, lower than that of "causing traffic accident" (>100\%). Although this does not constitute direct evidence of the involvement of illegal migrants in traffic accidents, it is fairly probable that fear of contact with the police leads illegal migrants to flee the scene after a traffic accident. Many illegal migrants do not have the resources to own or access a car, but those who do-for instance if they live with a legal partner or family_are not allowed to carry a Dutch driver's license, cannot have a car insurance, and risk repatriation if the police find them.

\section{ILLEGAL RESIDENCE AND NEIGHBORHOOD SAFETY IN BOSPOLDER-TUSSENDIJKEN AND DE SCHILDERSWIJK}

The fieldwork focused on illegal residence in relation to subjective neighborhood safety, but also provided some insights on illegal residence in relation to objective neighborhood safety. It helps us interpret and comment on two main aspects of the quantitative findings discussed. First, it illuminates why the negative effects of the presence of illegal migrants on neighborhood safety are modest at most. Second, it confirms that the consequences for neighborhood safety of the presence of illegal migrants are not unequivocal, and helps explain why.

\section{Why Are Not the Effects Stronger?}

Even in neighborhoods with elevated rates of illegal residence like in Bospolder-Tussendijken and De Schilderswijk, residents and professionals attribute unsafe feelings and discomfort primarily to phenomena other than illegal residence. Table 6 presents the reasons most often reported spontaneously. The three "causes" reported most often are: "junkies" (marginalized, problematic drug and alcohol users), "youths hanging around" (mostly boys, aged 12 to 25, often second- or third-generation Moroccans and Antilleans, who gather on certain street corners), and "sexually obtrusive men" (men approaching women with sexual propositions). Only two residents attribute their unsafe feelings explicitly to illegal migrants. One Turkish girl and one Moroccan girl were annoyed because youths sometimes approach minority girls in public space in order to make contact with potential partners who could help them obtain a residence permit.

In order to understand why the degree of illegal residence has limited effects on neighborhood safety and in order to stipulate the conditions under which stronger effects are to be expected, it is helpful to describe why residents feel unsafe in connection with these three social categories.

\section{TABLE 6}

Neighborhood-Related "Causes" of Unsafe Feelings and Discomfort Among 101 Residents in Bospolder-Tussendijken and De Schilderswijk

\begin{tabular}{lr}
\hline & $N$ \\
\hline Drug users, dealers, alcoholics & 18 \\
Youth hanging around (especially of Moroccan or Antillean origin) & 15 \\
Men sexually harassing women, stalkers & 9 \\
Delinquents in the streets & 5 \\
Dominant presence of a "hostile" ethnic group (including "skinheads") & 5 \\
Violent victimization (assault and robbery in public space) & 3 \\
People behaving incoherently & 3 \\
Appearance of properties (boarded windows, windows with curtains closed) & 2 \\
"lllegals" & 2 \\
Unknown languages being spoken in the street & 2 \\
Shouting people in the street ("they might as well be strangling someone") & 1 \\
\hline
\end{tabular}


The fear of drug addicts, youths hanging around, and obtrusive men is primarily due to their alleged involvement in norm violations, including crime. Drug addicts are often associated with robbery and pickpocketing, because they are assumed to be in need of money to buy drugs. Youths hanging around are associated with physical assault, robbery, threatening behavior, and sexual crimes. They are feared in particular because they operate in groups, and may join forces. Women in particular feel unsafe because of the behavior of sexually obtrusive men, who are sometimes suspected of being potential rapists and murderers. Although most respondents have never been victimized by drug addicts, groups of youths, or obtrusive men, many report unpleasant encounters with them, because they violate informal street rules quite frequently and openly.

Residents tend to interpret violations of informal rules as symptoms of underlying deviant identities, and consequently as omens of more serious dangers. The interviews suggest that at least three important informal rules are broken, although this street etiquette is rarely defined explicitly. First, all three categories (drug addicts, youth groups, and obtrusive men) fail to comply with the rule of civil inattention (Goffman, 1963). This rule dictates that participants in social traffic are expected to show coparticipants that they have been noticed, but if the coparticipant is a stranger, to do so only subtly. Youth groups and obtrusive men often fail to leave people in peace. Marginalized drug addicts violate this rule when they ask passers-by for money or food.

The second street law is the prescription that one must not appropriate too much public space (privatizing public space, Lofland, 1973). Marginalized drug users do not live up to this standard, since they live in the streets most of the time. But this rule is violated predominantly by youths who define their turf in public space at "hang-out spots" (Clay, 1973). They announce their territorial claims to outsiders by producing noise, and may treat passers-by with verbal aggression.

The third rule prescribes the right dose of situational involvement (Goffman, 1963). A participant (like the noisy street youth) must show neither too much involvement nor too little. This stipulation explains why many residents feel unsafe when people use drugs or alcohol in public, or appear to be confused. They are both unreachable and unpredictable, and therefore believed to be susceptible to transgressing other street rules or the law.

Illegal residence status is primarily an administrative status that is not directly visible in public space. Therefore, some members of the most feared social categories (drug addicts, youth group members, and obtrusive men) may be illegal migrants, and their illegal residence status may have contributed to their deviancy, even if the local residents are unaware of it. The police officers maintain that drug addiction may indeed develop among illegal migrants. Substance dependency usually corresponds with homelessness and/or is preceded by a career as a clean street merchant. Sometimes having illegal residence status may also, to a more limited extent, become associated with behavior that is typical for obtrusive men, such as with the boys approaching girls in hopes of obtaining a residence permit though a partner. Illegal residence has hardly any relation, however, to the phenomenon of street youths; not only do expulsion risks decrease the social opportunity to protect a turf by means of expressive dominant behavior, most illegal migrants, who have an average age of 30 years in The Netherlands, are also a bit too old for it.

Five reasons were found that help explain why the rate of illegal residence does not have stronger negative consequences for neighborhood safety. The first reason is that the legal population often depends on illegal migrants. Numerous residents, for instance, profit economically from their presence. Local shopkeepers profit from their capacity for work and the additional clientele they represent. Private individuals exploit dosshouses or sublet parts of their apartments. Furthermore, there are affective ties between the legal and illegal population. The illegal migrants who were interviewed - especially those from countries from which previous migration flows originatedoften had legal close relatives or a partner in the neighborhood. 
TABLE 7

Perceptions on Illegal Migrants in De Schilderswijk and Bospolder-Tussendijken, by Having Contacts with Illegal Migrants ${ }^{\mathbf{a}}$

\begin{tabular}{|c|c|c|c|c|c|c|}
\hline \multirow[b]{3}{*}{ Images of illegal migrants. They ... } & \multicolumn{3}{|c|}{ Bospolder-Tussendijken } & \multicolumn{3}{|c|}{ De Schilderswijk } \\
\hline & \multicolumn{2}{|c|}{ Contact } & \multirow[b]{2}{*}{ Total } & \multicolumn{2}{|c|}{ Contact } & \multirow[b]{2}{*}{ Total } \\
\hline & Yes & No & & Yes & No & \\
\hline "Have come here to work" & 9 & 4 & 13 & 22 & 8 & 30 \\
\hline "Keep more quiet" & 3 & 5 & 8 & 13 & 13 & 26 \\
\hline "Are people like you and me" & 5 & 3 & 8 & 11 & 8 & 19 \\
\hline "Commit crimes/are into crime" & 9 & 3 & 12 & 5 & 6 & 11 \\
\hline "Are being exploited/are pitiful" & 3 & 1 & 4 & 4 & 4 & 8 \\
\hline "Oust/displace regular residents" & 2 & 4 & 6 & 3 & 3 & 6 \\
\hline "Are nicer/more tidy" & 2 & 3 & 5 & 7 & 0 & 7 \\
\hline "Are illegal for a suspicious reason" & 1 & 1 & 2 & 0 & 4 & 4 \\
\hline "Harass women" & 1 & 1 & 2 & 1 & 2 & 3 \\
\hline "Cause nuisance by overcrowding" & 1 & 1 & 2 & 1 & 2 & 3 \\
\hline "Cause serious nuisance" & 2 & 0 & 2 & 1 & 2 & 3 \\
\hline "Tarnish good name of neighborhood/group" & 2 & 3 & 5 & 0 & 0 & 0 \\
\hline "Live in unsafe buildings" & 0 & 1 & 1 & 4 & 0 & 4 \\
\hline "Use drugs" & 0 & 3 & 3 & 1 & 0 & 1 \\
\hline "Carry infectious diseases" & 1 & 0 & 1 & 0 & 1 & 1 \\
\hline Total & 41 & 33 & 74 & 73 & 53 & 126 \\
\hline
\end{tabular}

aultiple images per respondent possible.

The second reason is the limited magnitude of concentrated illegal residence. In neighborhoods like Bospolder-Tussendijken and De Schilderswijk, the presence of illegal migrants rarely dominates activities and social relations in the neighborhood, even if the rate of illegal residence may be as high as $8 \%$. As can be seen from the listing of residents' images of illegal migrants documented in Table 7, most residents are indifferent or ambivalent about illegal residence in their neighborhood. Some residents support illegal migrants, for example, by providing language classes as volunteers, although they do not have other ties to the beneficiaries. Illegal residence only became a prominent issue in De Schilderswijk when the relative number of illegal Bulgarians suddenly grew strongly after visa requirements were eased and became very visible at some sites (see also Van Gestel, 2006).

The third reason, which is related to the first, is that illegal immigration does not increase anomie substantially. Most illegal migrants rent a room or apartment for extended periods of time, or form mixed households with legal residents. The ethnic and cultural diversity also hardly increases because of illegal settlement: concentration neighborhoods have very diverse populations, quite apart from the effects of illegal residence. Besides this, many illegal migrants are from countries that have been a source of legal flows for some time now, or are culturally not very distant from them. Nonetheless, some evidence was found that anomie increases in the vicinity of dosshouses, also called turnover houses by the local residents because of their unstable populations.

Fourth, the tolerant attitude toward illegal residence is, in part, compatible with a neighborhood culture that puts up with light norm violations. It turned out that many respondents feel secure and at home there in spite of elevated local crime rates. Many residents have become accustomed to the prevailing circumstances, and those who did not have moved. In these ways, the neighborhood 
conditions form and select residents who are not so easily annoyed by behavior that is uncivilized and antisocial according to upper and middle class Western standards (see also Elias, 1939). This is a matter of degree; we have seen that the residents definitely value certain informal and criminal laws. Interestingly, illegal residence as such was usually only seen as a minor violation at most. As a consequence, strong unsafe feelings are generally not triggered if residents believe they encounter such migrants, for example, when they pass dosshouses, witness police crackdowns aimed at these premises, or if the labor inspectorate checks whether local employers are employing illegal migrants.

The fifth and final reason is that illegal status does not have unequivocal consequences for rule transgression, also in the opinion and experience of neighborhood residents and the professionals. This final reason is explained in the next section.

\section{Why Is the Effect Not Unequivocal?}

It was found that the opinions on illegal residents are ambivalent and conflicting (Table 7). On the one hand, many residents have the impression that having illegal residence status promotes law-abiding behavior. By implication, illegal migrants are assumed to live quieter lives than people who are more certain of their civil rights. On the other hand, respondents (often the same ones) suppose that illegal migrants might become involved in crime because they are not allowed to work and are excluded from unemployment benefits.

While these perceptions are partially based on assumptions and stories in the media, they are in several ways in keeping with the available figures. Not only do these perceptions confirm our statistical findings. It also turns out that the residents in Rotterdam associate illegal residence with crime more frequently than the respondents in The Hague (Table 7). The relative number of illegal migrants who have been arrested because of crimes is indeed higher in the former than in the latter neighborhood. The professionals attribute this neighborhood difference to the problem of unoccupied dwellings and persistent drug tourism that used to plague the Rotterdam area. Especially during the 1990s criminal illegal migrants who spoke French traveled to Rotterdam in the wake of flows of drug consumers, mostly French citizens. These users were attracted by the favorable price and quality of the drugs available — as a trading nation, The Netherlands is an important country of import and redistribution of drugs-and, for them, Rotterdam was conveniently located in the south of Holland, a few hours driving time from France. Some North African illegal migrants who initially came to The Netherlands for other reasons found work in this black economy as well (Van der Leun, 2003).

Although most residents are not personally acquainted with criminal illegal migrants, the policemen told us that criminal careers may indeed develop among illegal residents, especially in the case of drug addiction. In their view, substance dependency usually corresponds with homelessness and/or is preceded by drug dealing as a clean street merchant (drug dealing is a variant of subsistence crime that is, for the most part, not measured by the PM survey). Without being prompted, the policemen also mentioned the phenomenon of criminal migration and transnational brigandage. In both neighborhoods, there had been problems with Eastern European car thieves.

A larger number of respondents know illegal migrants who do not commit crimes. They knowand the professionals confirm this-that these people are generally very careful. A Moroccan girl mentioned how three of her illegal acquaintances spend most of their time in their rooms or at a Moroccan cafe, hoping one day to marry. A Dutch woman remembers that she never had such quiet neighbors as when there were illegal migrants in the apartment above hers: "It sometimes seemed as if they crept along their ceiling." 
The assertion that illegal migrants live quietly should not be exaggerated. Eventually, illegal newcomers find out that in The Netherlands one rarely has to show an ID to the police, as long as one remains within the law. In addition, the police do not always take great pains to repatriate illegal migrants. Random raids are prohibited. A community police officer in Rotterdam acknowledged that there have been illegal migrants in the neighborhood for years: "We don't do anything about it as long as they don't cause trouble." Refugees in particular, and migrants with strong social ties in The Netherlands such as family members or a partner, try to avoid expulsion. This tendency is stronger among migrants who believe they will have few opportunities to return. Other illegal migrants are less concerned about expulsion. An official of the immigration service explained that from time to time illegal Eastern Europeans turn themselves in voluntarily because they want to be transported back free of charge. Because the geographical distance to their country of origin is smaller, and because of their status as future citizens of EU-member countries, Eastern Europeans could take more liberties about being openly visible in the neighborhoods than other illegal migrants. They were sometimes associated with types of nuisance that are quite atypical for migrants without a residence permit. A square in The Hague was known locally as the Bulgarenplein (Bulgarians Square) for a while because every day hundreds of Bulgarians used to gather in front of a Turkish café, which served as a meeting point and illegal temp agency for horticultural labor in a nearby area. Eventually, the police intervened because of complaints (see also Van Gestel, 2006). Illegal migrants who are difficult to expel are a second exception; typically they have been put in Aliens' Detention at least once, but released because they concealed their identity, or because their country of origin did not cooperate with repatriation. One of the authors conducted interviews in an Aliens' Detention facility and found that seriously marginalized illegal migrants sometimes preferred a temporary stay in detention to life on the street (Leerkes, 2009).

Some comments are in order about the assumption that illegal migrants' fear of detention and repatriation always favor the safety of the local residents. We have already reported that illegal migrants have an interest in leaving the scene if they become involved in a traffic incident. We were also told that some illegal migrants are apt to leave the curtains closed so they cannot be seen. Observing unopened curtains during the day is sometimes interpreted as an informal norm violation that makes some neighbors and passers-by feel unsafe (see Table 6). In The Netherlands, it is common practice to leave the curtains open most of the time.

In general, however, illegal migrants are more likely to comply with state rules, precisely because they are not supposed to be in The Netherlands. The weak cannot take the same liberties to violate rules overtly as the more powerful, legal residents (cf. Scott, 1990; Collins, 2008). The fieldwork suggests that illegal migrants do not only tend to break formalized state rules in a relatively reserved, secretive and selective way (there was already some evidence for this); they exhibit the same patterns of compliance with unwritten street codes. Violation of informal street etiquette may provoke state action as well, especially in cases of escalation. Usually, these informal rules are transgressed, if at all, selectively, such as by illegal boys who approach potential marriage partners. The chief exception here is the minority of illegal migrants who are addicted to alcohol or drugs and have become homeless: they may break more than one type of social rule.

We have now come closer to solving our paradoxical quantitative finding that the rate of illegal residence does not worsen subjective neighborhood safety, even if it does appear to increase property crime. First, illegal migrants do not appear to violate unwritten street rules with high frequency, while such overt deviant behavior is a substantial factor in perceived neighborhood safety. Second, illegal offenders are not very often involved in violence, whereas the association between criminal victimization and subjective safety tends to pertain to violent crimes rather than to property crime (Miceli, Roccato, \& Rosato, 2004; Moore \& Shepherd, 2006). Third, residents in concentration areas appear to be relatively inured to minor norm violations; they do not very easily feel unsafe, and may also be less likely to answer in the PM survey that "much" 
offending takes place in their area, even though this may well be the case according to objective criteria.

\section{CONCLUDING REMARKS}

It was demonstrated that illegal migrants are overrepresented in relatively unsafe neighborhoods, where considerable street crime occurs and where residents feel relatively unsafe. Yet, when individual and neighborhood variables that are known to determine neighborhood safety are kept constant, the effect of the rate of illegal residence on neighborhood safety diminishes, and eventually seems to reverse, although its relation with subjective neighborhood safety and livability becomes too small to be statistically detectable in the data. It turns out that indicators of social disorganization in particular explain the reduced perceived safety in neighborhoods where illegal migrants are concentrated.

Similar results were found with regard to the relationship between illegal residence and objective neighborhood safety. Yet, a modest positive relation remained between the rate of illegal residence and covert property crime rates in particular.

For several reasons, the opportunity structure for illegal residence is concentrated in disorganized urban neighborhoods that house a disproportionate segment of non-Western minority groups and singles (Leerkes et al., 2007). One of the reasons why illegal migrants and other poor newcomers find openings in unsafe neighborhoods is that many households with more social and financial resources tend to move out of these neighborhoods when they can. Therefore, it appears that the concentration of illegal residence is to a great degree not a cause but a consequence of insecurity. Illegal residence does not generate neighborhood differences in safety; neighborhood differences in safety are among the factors that generate differences in the concentration of illegal residence.

The fieldwork yielded five reasons why the presence of illegal migrants does not endanger neighborhood safety much: (1) there are economic and affective ties between legal and illegal residents; (2) in The Netherlands the rate of illegal residence is still relatively modest even in concentration areas; (3) the presence of illegal migrants does not increase anomie substantially; (4) the legal residents of the neighborhoods concerned are relatively tolerant of minor norm violations and most consider illegal residence as such a minor infraction; and (5) having illegal residence status does not have unequivocal consequences for norm violation and crime.

A major reason for conducting this explorative study was that concentrated illegal residence may promote a further decline of social organization, and therefore of safety. The fieldwork suggested that the presence of illegal migrants does not necessarily diminish social organization substantially, since it often concerns informal chain migration and labor migration. This finding is valid under the circumstances found in the two selected neighborhoods. When the percentage of illegal migrants exceeds a certain limit, or when substantial vagrant groups become part of the illegal population — which occurred in the Rotterdam crack houses for a while- there will be a higher chance of negative effects on social organization and, therefore, on neighborhood safety.

To date there is no other study on illegal residence and neighborhood crime. Yet, our findings agree with the tenor of recent research in the United States on crime and total immigration, that is, legal and illegal migration combined. It is found that while immigration increases social disorganization of urban neighborhoods to some extent (Sampson et al., 1997, p. 921), the involvement of first-generation migrants in crime, especially violent crime, is relatively low (Butcher \& Morrison Piehl, 1998; Hagan \& Palloni, 1999; Lee, Martinez, \& Rosenfeld, 2001; Reid, Weiss, Adelman, \& Jaret, 2005; Sampson, 2008). At the same time, our findings differ from 
Sampson's (2008), who reports that immigration improves neighborhood safety if all confounding factors are controlled; we did find a modest positive effect of the concentration of illegal migrants on property crime, and also observed negative effects of the percentage of legal non-Western migrants on most dimensions of objective and subjective neighborhood safety. We propose four explanations to account for these apparent discrepancies.

First, illegal migrants are less excluded from the labor market in the United States than they are in The Netherlands, although this difference is becoming smaller due to recent policy developments in the United States. Hence, the criminogenic effects of marginalization are probably relatively strong in The Netherlands, while the relative importance of deterrence is still likely to be high in the United States. Second, American researchers focus on the first generation, whereas the variable by Statistics Netherlands on the proportion of legal non-Western migrants includes first- and second-generation migrants. As a rule, street crime is more prevalent in the second generation than in the first generation. It turns out that second-generation migrants from several of the largest non-Western source countries are overrepresented in it to a greater extent than is the first generation, both in The Netherlands and in other EU countries (Haen-Marshall, 1997; Tonry, 1997; Engbersen et al., 2007). Third, the effects of immigration on street crime are more likely to appear small in empirical studies in the United States because of the implicit or explicit comparison with the elevated crime rate in the black urban population. The Netherlands and other countries in Western Europe lack a comparable high-crime native group. Fourth, the percentage of legal non-Western migrants is likely to be a stronger correlate of social disorganization in The Netherlands than it is in the United States: immigration flows in the latter country are relatively homogeneous because of the high share of Mexicans and other Hispanics, and the relative absence of migrants from Africa and the Middle East (for a comparison between the European and the North American international migration system see Massey et al., 2005).

A potential disadvantage of selecting two neighborhoods with elevated levels of illegal residence is that part of the residents who feel most threatened by it had probably already moved to other neighborhoods, leaving behind the residents who felt less threatened by it or were even positive about it. This selection effect may have led us to underestimate the influence of illegal residence on subjective neighborhood safety. At the same time, many residents in neighborhoods like Bospolder-Tussendijken and De Schilderswijk simply lack the resources to move, while some remain loyal to the neighborhood in spite of their critical opinion of certain neighborhood aspects. It would nonetheless be interesting to conduct additional fieldwork in a neighborhood where concerned residents relocate, in order to interview them as well. Such a fieldwork could also, more generally, examine whether immigration and illegal residence are feared in socially established neighborhoods that are not really experiencing these phenomena.

The safety of illegal migrants deserves more research. This study suggests that we should worry about their safety. They often live in unsafe districts. Many of them are young men and women. Admittedly, young men do not feel unsafe so quickly, but they do have an elevated risk of victimization depending on their lifestyle - think of the illegal men who start to sell drugs as a form of subsistence crime. Young illegal women may have a higher risk of sexual abuse. Because filing a charge with the police is riskier for illegal migrants than for citizens or legal denizens, they may be ideal crime victims.

ACKNOWLEDGEMENTS: Arjen Leerkes wishes to thank the Amsterdam School for Social Science Research (ASSR). A VENI grant by the Netherlands Organization for Scientific Research (NWO) also contributed to this research project. Translation/correction of this article was financed by the Translation Fund of the Royal Netherlands Academy of Arts and Sciences and Stichting Reprorecht. [Correction added on 21 June 2010 after first publication online on 21 April 2010: Acknowledgement section is now added.] 


\section{ENDNOTES}

1 For instance, in May 2007 the European Commission issued a Proposal for a Council Directive providing for sanctions against employers of illegally staying third country nationals (Carrera and Guild, 2007). The United States has recently adopted restrictive policies as well, including stricter law enforcement. In the past few years, a substantial number of American states have adopted measures to curb the employment of illegal immigrants and exclude them from public benefits (Jencks, 2007; NCSL, 2009).

2 Secondary analyses based on estimates by Leerkes et al. (2004) show that the annual risk of arrest for criminal illegal migrants is $13 \%$, against $6 \%$ for noncriminal illegal migrants. Because the probability that an address is recorded in the VAS is lower for criminal (20\%) than for noncriminal (33\%) apprehended illegal migrants, the former are on average $30 \%$ more likely to enter our neighbourhood measure of illegal residence.

3 Statistics Netherlands' official name of this variable is "persons not living in families." This also includes unmarried couples without children. For convenience sake, we use the term single-person households in this article. For The Netherlands as a whole, Statistics Netherlands reports that about $82 \%$ of this category consists of single-person households. See http://statline.cbs.nl for more details.

4 We also experimented with a more general measure of SES that was a factor score based on: (1) the average value of real estate in the neighborhood and (2) the average income of the neighborhood residents. This measure had a negative effect on neighborhood crime if no other predictors of neighborhood safety were included in the equation, indicating that street crime becomes more prevalent if SES decreases. Yet, contrary to percentage of low-income residents this variable did not have an independent effect when other determinants of neighborhood safety were added in a multiple regression equation. Note that we do not control for the number of potential offenders in the neighborhood when modeling subjective safety, as these models already include more precise measures of within-the-neighborhood victimization and neighborhood crime.

5 Yet, using residential mobility as a predictor of neighborhood safety is not unproblematic either. Neighborhood crime and safety are also, to a considerable extent, causes of neighborhood differences in residential mobility. This will inflate the coefficients of the effects of residential mobility on neighborhood safety.

6 The eigenvalue of the factor is 1.53 . Both variables have factor loadings of 0.87 on the factor; the correlation between the variables is 0.53 .

7 These six factors have the following eigenvalues (item factor loadings in parentheses) of 2.18 (factor loadings $0.66,0.73,0.57,0.54,0.77$ ), 2.05 (factor loadings $0.68,0.79,0.75,0.62$ ), 1.71 (factor loadings 0.71, 0.60, $0.60,0.72$ ), 2.54 (factor loadings $0.62,0.74,0.73,0.76,0.70$ ), 1.51 (factor loadings $0.72,0.64,0.76$ ), and 1.81 (factor loadings $0.74,0.61,0.68,0.60$ ).

8 Neighborhoods with a rate of illegal residence of at least one standard deviation above the mean have fewer people over the age of 65 (8.7\% against $14.2 \%$ in other urban neighborhoods) and more males (51.4\% against $48.7 \%$ elsewhere).

\section{REFERENCES}

Alt, J. (1999). Illegal in Deutschland. Forschungsproject zur Lebenssituation "illegaler" Migranten in Leipzig [Illegal in Germany. Research project on the life situation of 'illegal' migrants in Leipzig]. Kalsruhe, Germany: Von-Loeper Literaturverlag.

Alt, J. (2003). Leben in der Schattenwelt. Problemkomplex “illegale” Migration. Karlsruhe, Germany: Von Loeper Literaturverlag.

Angel-Ajani, A. (2003). A question of dangerous races? Punishment \& Society, 5, 433-448.

Bade, K. J. (2004). Legal and illegal immigration into Europe: Experiences and challenges. European Review, 12, 339-375.

Bernasco, W., \& Luykx, F. (2003). Effects of attractiveness, opportunity and accessibility to burglars on residential burglary rates of urban neighborhoods. Criminology, 41, 981-1002. 
Bigo, D. (2001). Migration and security. In V. Guiraudon \& C. Joppke (Eds.), Controlling a new migration world (pp. 121-149). London: Routledge.

Bourdieu, P. (1983). The forms of social capital. In J. Richardson (Ed.), Handbook of theory and research for the sociology of education (pp. 241-258). New York: Greenwood Press.

Brown, B., Perkins, D., \& Brown, G. (2003). Place attachment in a revitalizing neighborhood: Individual and block levels of analysis. Journal of Environmental Psychology, 23, 259-271.

Burgers, J. (1998). In the margin of the welfare state: Labor market position and housing conditions of undocumented immigrants in Rotterdam. Urban Studies, 35(10), 1855-1868.

Butcher, K., \& Morrison Piehl, A. (1998). Recent immigrants: Unexpected implications for crime and incarceration. Industrial and Labor Relations Review, 51(4), 654-679.

Carrera, S., \& Guild, E. (2007). An EU framework on sanctions against employers of irregular immigrants: Some reflections on the scope, features and added values. CEPS Policy Brief No. 140, 1 August 2007.

Clay, G. (1973). Close-up: How to read the American city. New York: Praeger.

Collins, R. (2008). Violence. A micro-sociological theory. Princeton, NJ: Princeton University Press.

Cornelius, W., Tsuda, T., Martin, P., \& Hollifield, J. (Eds.) (2004). Controlling immigration: A global perspective. Stanford, CA: Stanford University Press.

Courau, H. (2008). Undocumented migration: Counting the uncountable. Data and trends across Europe. Country report France. Athens: Clandestino.

Covington, J., \& Taylor, R. (1991). Fear of crime in urban residential neighborhoods: Implications of between- and within-neighborhood sources for current models. The Sociological Quarterly, 32(2), 231249.

Davies, P., Francis, P., \& Jupp, V. (2003). Victimization: Theory, research and policy. Basingstoke, UK: Palgrave Macmillan.

De Bakker, E. (2001). De cynische verkleuring van legitimiteit en acceptatie: een rechtssociologische studie naar de regulering van seizoensarbeid in de aspergeteelt van Zuidoost-Nederland [The cynical fading of legitimacy and acceptation: A sociological study on the regulation of seasonal labor in the asparagus cultivation in the South-east of The Netherlands]. Amsterdam: Aksant.

Dijkink, W. (1987). Politie en omgeving: kennis en beleid rond de criminaliteit in Amsterdam [Police and environment: Knowledge and policy surrounding crime in Amsterdam]. Utrecht: Van Arkel.

Ditton, J., \& Farrall, S. (Eds.) (2000). The fear of crime. Aldershot, UK: Ashgate.

Düvell, F. (Ed.) (2006). Illegal immigration in Europe: Beyond control? Basingstoke, UK: Palgrave Macmillan.

Ehrenreich, B. (2002). Global woman: Nannies, maids, and sex workers in the new economy. New York: Metropolitan Books.

Elias, N. (1939). Über den Prozess der Zivilisation: Soziogenetische und psychogenetische Untersuchungen [The civilizing process: Sociogenetic and psychogenetic investigations]. Basel: Haus zum Falken.

Elias, N., \& Scotson, J. (1965). The established and the outsiders: A sociological enquiry into community problems. London: Cass.

Engbersen, G. (1996). The unknown city. Berkeley Journal of Sociology, 40, 87-112.

Engbersen, G. \& Van der Leun, J. (2001). The social construction of illegality and criminality. European Journal on Criminal Policy and Research, 9(1), 51-70.

Engbersen, G., Van der Leun, J., \& De Boom, J. (2007). The fragmentation of migration and crime. In M. Tonry \& C. Bijleveld (Eds.), Crime and justice: A review of research (Special issue on Crime and Justice in The Netherlands) (pp. 389-452). Chicago: University of Chicago Press.

Engbersen, G., Van San, M., \& Leerkes, A. (2006). A room with a view: Irregular immigrants in the legal capital of the world. Ethnography, 7, 209-242.

Goffman, E. (1963). Behavior in public places: Notes on the social organization of gatherings. London: The Free Press of Glencoe.

Goffman, E. (1971). Relations in public: Microstudies of the public order. New York: Basic Books.

Goudriaan, H., Wittebrood, K., \& Nieuwbeerta, P. (2006). Neighborhood characteristics and reporting crime: Effects of social cohesion, confidence in police effectiveness, and socio-economic disadvantage. British Journal of Criminology, 46, 719-742.

Haen-Marshall, I. (Ed.) (1997). Minorities, migrants, and crime: Diversity and similarity across Europe and the United States. Thousand Oaks, CA: Sage. 
Hagan, J., \& Palloni, A. (1999). Sociological criminology and the mythology of Hispanic immigration and crime. Social Problems, 46(4), 617-632.

Hale, C. (1996). Fear of crime: A review of the literature. International Review of Victimology, 4, 79-150.

Hannon, Lance E. (2005). Extremely poor neighborhoods and homicide. Social Science Quarterly, 86, $1418-1434$.

Hannon, L., \& Knapp, P. (2003). Reassessing nonlinearity in the urban disadvantage/violent crime relationship: An example of methodological bias from log transformation. Criminology, 41, 1427-1448.

Huysman, J. (2000). The European Union and the securitization of migration. Journal of Common Market Studies, $38(5), 751-777$.

Jencks, C. (2007). The immigration charade. New York Review of Books, 54(14), 49-52.

Killias, M. (1990). Vulnerability: Towards a better understanding of a key variable in the genesis of fear of crime. Violence and Victims, 5, 97-108.

Kornhauser, R. (1978) Social sources of delinquency. Chicago: University of Chicago Press.

Lee, M., Martinez, R., \& Rosenfeld, R. (2001). Does immigration increase homicide? Negative evidence from three border cities. Sociological Quarterly, 42(4), 559-580.

Leerkes, A. (2004). Embedded crimes? On the overlapping patterns of delinquency among legal and illegal immigrants in The Netherlands. The Netherlands Journal of Social Sciences, 40, 3-23.

Leerkes, A. (2009). Illegal residence and public safety in The Netherlands. Amsterdam: Amsterdam University Press.

Leerkes, A., Engbersen, G., \& Van San, M. (2007). Shadow places: Patterns of spatial concentration and incorporation of irregular immigrants in The Netherlands. Urban Studies, 44(8), 1491-1516.

Leerkes, A., Van San, M., Engbersen, G., Cruijff, M., \& Van der Heijden, P. (2004). Wijken voor illegalen. Over ruimtelijke spreiding, huisvesting en leefbaarheid [Neighborhoods for illegal migrants. On spatial spreading, housing and liveability]. Den Haag: SdU.

Lewis, D., \& Salem, G. (1986). Fear of crime: Incivility and the production of a social problem. New Brunswick, NJ: Transaction.

Lofland, L. (1973). A world of strangers: Order and action in urban public space. New York: Basic Books.

Mahler, S. (1995). American dreaming: Immigrant life on the margins. Princeton, NJ: Princeton University Press.

Markowitz, F., Bellair, P., Liska, A., \& Liu, J. (2001). Extending social disorganization theory: Modeling the relationship between cohesion, disorder, and fear. Criminology, 39, 293-320.

Martin, P. (2004). The United States: The continuing immigration debate. In W. Cornelius et al. (Eds.), Controlling immigration: A global perspective (pp. 51-85). Stanford, CA: Stanford University Press.

Massey, D., Arango, J., Hugo, G., Kouaouchi, A., Pellegrino, A., \& Taylor, E. (2005). World in motion: Understanding international migration at the end of the millenium. Oxford: Clarendon Press.

McDonald, W. (1997). Illegal immigration: Crime, ramifications and control (The American experience). In W. McDonald (Ed.), Crime and law enforcement in the global village (pp. 65-86). Cincinnati, OH: Anderson Publishing Company.

Miceli, R., Roccato, M., \& Rosato, R. (2004). Fear of crime in Italy: Spread and determinants. Environment and Behavior, 36, 776-789.

Moore, S., \& Shepherd, J. (2006). The cost of fear: Shadow pricing the intangible costs of crime. Applied Economics, 38, 293-300.

National Conference of State Legislatures (NCSL) (2009). State laws related to immigrants and immigration in 2008. Washington, DC: NCLS.

Ngai, M. (2004). Impossible subjects: Illegal aliens and the making of modern America. Princeton, NJ: Princeton University Press.

Portes, A. (1998). Social capital: Its origins and applications in modern sociology. Annual Review of Sociology, $24,1-24$.

Reid, W., Weiss, H., Adelman, A., \& Jaret, C. (2005). The immigration-crime relationship: Evidence across US metropolitan areas. Social Science Research, 34, 757-780.

Sampson, R. (2008). Rethinking crime and immigration. Contexts, 7(1), 28-33.

Sampson, R., \& Laub, J. (1993). Crime in the making: Pathways and turning points through life. Cambridge, MA: Harvard University Press.

Sampson, R., Raudenbush, S., \& Earls, F. (1997). Neighborhoods and violent crime: A multilevel study of collective efficacy. Science, 277(5328), 918-924. 
Sassen, S. (1991). The Global City: New York, London, Tokyo. Princeton, NJ: Princeton University Press.

Scalia, J. (1996). Noncitizens in the federal criminal justice system, 1984-1994. Washington, DC: U.S. Department of Justice, Bureau of Justice Statistics.

Scalia, J. (2002). Immigration offenders in the federal criminal justice system, 2000. Washington, DC: U.S. Department of Justice, Bureau of Justice Statistics.

Schloenhardt, A. (2001). Trafficking in migrants: Illegal migration and organized crime in Australia and the Asia Pacific region. International Journal of the Sociology of Law, 29, 331-378.

Schoen, E., Defize, P., \& Bakker, M. (2000). Methodologische evaluatie van de Politiemonitor Bevolking [Methodological evaluation of the police monitor population]. Delft: TNO.

Scott, J. (1990). Domination and the arts of resistance: Hidden transcripts. New Haven, CT: Yale University Press.

Shaw, C., \& McKay, H. (Eds.) (1942). Juvenile delinquency and urban areas: A study of rates of delinquency in relation to differential characteristics of local communities in American cities. Chicago: University of Chicago Press.

Taylor, R. (1996). Neighborhood responses to disorder and local attachments: The systemic model of attachment, social disorganization, and neighborhood use value. Sociological Forum, 11(1), 41-74.

Taylor, R., \& Hale, M. (1986). Testing alternative models of fear of crime. Journal of Criminal Law and Criminology, 77, 151-189.

Tonry, M. (Ed.) (1997). Ethnicity, crime, and immigration: Comparative and cross-national perspectives. Chicago: University of Chicago Press.

Van der Leun, J. (2003). Looking for loopholes: Processes of incorporation of illegal immigrants in The Netherlands. Amsterdam: Amsterdam University Press.

Vanderveen, G. (2006). Interpreting fear, crime, risk and unsafety. $\mathrm{PhD}$ Thesis, Erasmus Universiteit Rotterdam.

Van Gestel, B. (2006). Nieuws, beleid en criminaliteit. Over de wisselwerking tussen lokale media en criminaliteitsbestrijders [News, policy, and crime. About the interaction between local media and crime fighters]. Amsterdam: Aksant.

Van Heek, F. (1936). Chineesche immigranten in Nederland [Chinese immigrants in The Netherlands]. Amsterdam: N.V. J. Emmering's Uitgevers.

Van Meeteren, M., Van San, M., \& Engbersen, G. (2008). 'Zonder papieren': over de positie van irreguliere migranten en de rol van het vreemdelingenbeleid in Belgie ['Without papers': On the position of irregular migrants and the role of the aliens policy in Belgium]. Leuven: Acco.

Van Ommeren, J. (2006). Verhuismobiliteit: een literatuurstudie naar belemmeringen tot verhuizen [Residential mobility: A literature review on impediments for moving]. Amsterdam: Vrije Universiteit.

Van Tilburg, W., \& Lammers, J. (2004). Landelijke criminaliteitskaart 2003. Een analyse van geregistreerde misdrijven en verdachten op basis van HKS-gegevens [National Crime Map 2003. An analysis of documented crimes and suspects]. Zoetermeer: KLPD-NRI.

Van Wilsem, J., Wittebrood, K., \& De Graaf, N. (2006). Socioeconomic dynamics of neighborhoods and the risk of crime victimization: A multilevel study of improving, declining, and stable areas in The Netherlands. Social Problems, 53, 226-247.

Veléz, M. (2001). The role of public social control in urban neighborhoods: A multilevel analysis of victimization risk. Criminology, 39, 837-864.

Wei, E., Hipwell, A., Pardini, D., Beyers, J., \& Loeber, R. (2005). Block observations of neighborhood physical disorder are associated with neighborhood crime, firearm injuries and deaths, and teen births. Journal of Epidemiology and Community Health, 59, 904-908.

Wolf, D. (1988). Undocumented aliens and crime: The case of San Diego County. San Diego, CA: University of California, Center for U.S.-Mexican Studies.

Zaitch, D. (2002). Trafficking cocaine: Colombian drug entrepreneurs in The Netherlands. Den Haag: Kluwer Law International. 